\title{
Akhlak Islami dan Kesehatan Mental
}

\author{
Drs H. Mustopa, M.Ag. ${ }^{1}$
}

\begin{abstract}
Abstrak
Diskursus tentang akhlak seakan tak pernah habis dan selalu saja menyedot perhatian banyak pihak, baik dari kalangan teoretisi maupun dari kalangan praktisi dan akademisi. Akhlak seringkali menjadi barometer dari kejiwaan dan kesehatan mental seseorang. Hal ini tidak bisa dinegasikan mengingat dalam banyak kasus ditemukan orang yang akhlaknya tidak baik ternyata mentalnya tidak sehat. Dengan kata lain; orang yang mentalnya tidak sehat ternyata berimplikasi kepada munculnya akhlak (sikap dan perilaku) yang juga tidak baik. Ini sesungguhnya menunjukkan bahwa akhlak memiliki hubungan yang signifikan dengan kesehatan mental, begitupun sebaliknya, yakni orang yang akhlaknya tidak baik mentalnya pun tidak baik (kesehatan mentalnya terganggu).
\end{abstract}

Kata Kunci: Akhlak, Akhlak Islami dan Kesehatan Mental.

\section{PENDAHULUAN}

Rasulallah saw diutus oleh Allah swt ke dunia salah satu misinya adalah untk menyempurnakan akhlak manusia. Kehadiran Rasulallah sebagai pengemban misi penyempurna akhlak manusia ini menunjukkan betapa pentingnya akhlak bagi manusia dalam menjalani hidup dan kehidupannya. Akhlak yang berdasar-kan pada ajaran-ajatan agama Islam disebut sebagai akhlak Islami. Akhlak Islami merupakan suatu sifat yang harus dimiliki dan sekaligus diamalkan oleh siapapun yang merasa dirinya sebagai Muslim.

Akhlak Islami penting untuk dimiliki oleh manusia (terutama Muslim). Hal ini mengingat karena dengan akhlak Islami manusia akan mampu menempatkan dirinya baik terhadap Allah swt sebagai penciptanya, sesama manusia sebagai sesame hambanya yang berakal ataupun terhadap lingkungan alam sekitarnya.

Kemampuan manusia memposisikan dirinya (berakhlak) kepada Allah swt, kepada sesame manusia dan kepada lingkungan alam sekitarnya akan membuat dirinya terlepas dari perasaan bersalah dan dosa, sehingga pada gilirannya akan terbentuklah jiwa yang terbebas dari penyakit jiwa dan zsehat mentalnya.

Dalam pengertian yang amat sederhana kesehatan mental itu sudah dikenal sejak manusia pertama (Adam), karena Adam as itu pertama merasa berdosa yang menyebabkan jiwanya gelisah dan hatinya sedih. Untuk menghilangkan

${ }^{1}$ Penulis adalah dosen Fakultas Ushuluddin Adab dan Dakwah (FUAD) Prodi Filsafat Islam Institut Agama Islam (IAIN) Syekh Nurjati Cirebon Jawa Barat. 
kegelisahan dan kesedihan tersebut, ia bertaubat kepada Allah dan taubatnya diterima serta ia merasa lega kembali. Firman Allah SWT:

Artinya: Kemudian Adam menerima beberapa kalimat, ${ }^{2}$ dari Tuhannya, Maka Allah menerima taubatnya. Sesungguhnya Allah Maha Penerima Taubat lagi Maha Penyayang. ${ }^{3}$

Ayat di atas menunjukkan taubat dari kesalahan dapat membebaskan diri dari perasaan salah dan berdosa. Dengan demikian maka timbullah perasaan tenag yang kemudian akan melahirkan jiwa yang tenang dan perilaku atau akhlak yang baik. Dengan demikian tidak dapat dinegasikan adanya hubungan antara akhlak dengan kesehatan mental manusia.

\section{PEMBAHASAN}

\section{A. Akhlak}

\section{Definisi Akhlak}

Berbicara tentang akhlak, maka bisa dipastikan istilah ini sudah sangat familier di telinga siapapun, karena istilah akhlak tak bisa dipisahkan dari sikap manusia sehari-hari. Ada dua pendekatan yang dapat digunakan untuk mendefinisikan akhlak, yaitu dengan pendekatan linguistik (kebahasaan), dan pendekatan terminologi (peristilahan). ${ }^{4}$

Berdasarkan sudut kebahasaan, akhlak berasal dari bahasa Arab, yaitu isim mashdar (bentuk infinitif) dari kata akhlaqa, yukhliqu, ikhlaqan, sesuai dengan timbangan (wazan) tsulasi majid: af'ala, yuf'ilu if'alan yang berarti al-sajiyah (perangai), ath-thabi'ah (kelakuan, tabi'at, watak dasar), al-'adat (kebiasaan, kelaziman), al-maru'ah (peradaban yang baik), dan al-din (agama). ${ }^{5}$

Adapun secara terminologi, pengertian akhlak sebagaimana yang dipaparkan oleh beberapa ahli, diantaranya adalah Imam Al-Ghazali mendefinisikan akhlak dengan : Sifat yang tertanam dalam jiwa yang dengannya lahirlah berbagai macam dengan gampang dan mudah tanpa memerlukan pemikiran dan pertimbangan. ${ }^{6}$ Sedangkan Ahmad Amin memberikan uraian

2 Tentang beberapa kalimat (ajaran-ajaran) dari Tuhan yang diterima oleh Adam sebahagian ahli tafsir mengartikannya dengan kata-kata untuk bertaubat.

${ }^{3}$ Q.S. Al Baqarah: 37.

${ }^{4}$ Abuddin Nata. Akhlak Tasawuf dan Karakter Mulia. Jakarta; PT. RajaGrapindo Persada. 2014., hlm., 1

${ }^{5}$ Jamil Shaliba, al-Mu'jam al-Falsafi, Juz I, Mesir: Dar al-Kitab al-Mishri, 1978, hlm.539.; Kamus Besar Bahasa Indonesia, Jakarta: Balai Pustaka, 1991, hlm.19.

${ }^{6}$ Al-Ghazali, Ihyâ 'Ulûm al-Dîn. jilid 3. Beirut : Dar al-Fikr, t.t., hlm. 56. Dalam bahasa aslinya

عبارة عن هيئة في النقس راسخة عنها تصدر الافعال بسهولة ويسر من غير حاجة الي فكر وروية 
tentang definisi akhlak. Menurutnya akhlak adalah menangnya keinginan dari beberapa keinginan manusia dengan langsung dan berturut. ${ }^{7}$

Ibn Miskawaih. ${ }^{8}$ Menjelaskan Akhlak adalah : Sifat yang tertanam dalam jiwa yang memotivasinya untuk melakukan perbuatan tanpa memerlu-kan pemikiran dan pertimbangan. Rachmat Djatnika menjelaskan akhlak berasal dari bahasa Arab Akhlâq bentuk jama dari mufradnya adalah khuluq, yang berarti "budi pekerti". Sinonimnya : etika dan moral. Etika berasal dari bahasa Latin, etos yang berarti "kebiasaan". Moral berasal dari bahasa Latin juga, mores, juga berarti "kebiasaannya". 9

Zakiah Darajat menjelaskan kata akhlak secara etimologi (arti bahasa) berasal dari kata khalaqa, yang kata asalnya khuluqun, yang berarti : perangai, tabiat, adat atau khalqun yang berarti kejadiaan, buatan, ciptaan. Jadi secara etimologi akhlak itu berarti perangai, adat, tabiat, atau sistem perilaku yang dibuat. ${ }^{10}$ Karenanya, akhlak secara kebahasaan bisa baik atau buruk tergantung kepada tata nilai yang dipakai sebagai landasannya, meskipun secara sosiologis di Indonesia kata akhlak sudah mengandung konotasi baik, jadi orang berakhlak berarti orang yang berakhlak baik. ${ }^{11}$

Terkait dengan masalah akhlak, Allah SWT berfirman dalam Al-Quran yang menyatakan bahwa Muhammad Rasulallah memiliki akhlak yang mulia (agung) :

Artinya: Dan Sesungguhnya kamu benar-benar berbudi pekerti yang agung. ${ }^{12}$

Artinya: (Agama kami) Ini tidak lain hanyalah adat kebiasaan orang dahulu. ${ }^{13}$

Pengertian akhlak dalam Ensiklopedi Islam dijelaskan sebagai suatu keadaan yang melekat pada jiwa manusia yang dari padanya lahir perbuatanperbuatan dengan mudah, tanpa melalui proses pemikiran, atau penelitian. ${ }^{14}$

${ }^{7}$ Ahmad Amin, Al-akhlâq. terjemahan Farid Ma'ruf dalam "Etika (Ilmu akhlaq). Jakarta : Penerbit Bulan Bintang, 1988), hlm. 25. Selanjutnya ditulis Ahmad Amin, Al-akhlâq

8 Ibn Miskawaih, Tahdzîb al-Akhlâq wa Tathhîr al-A'raq. Mesir : al-Maktabat alMishriyyah, 1934., hlm 40.

حال للنفس داعية لها الي افعالها من غير فكر ولا روية

${ }^{9}$ Rachmat Djatnika. Sistem Ethika Islami. Jakarta : Pustaka Panji Mas, 1969., hlm. 26

${ }^{10}$ Zakiah Darajat, dkk. Materi Pokok Pendidikan Agama Islam. Jakarta : Proyek Pembinaan Pendidikan Agama Isslam Pada Perguruan Tinggi Depag dan Universitas Terbuka Depdikbud. 1993., hlm. 238. Selanjutnya ditulis Zakiah Darajat, dkk. Materi Pokok

${ }^{11}$ Zakiah Darajat, dkk. Materi Pokok Ibid.,

12 QS. Al-Qalam : 4

${ }^{13}$ QS. Asy-Su'ara : 137

${ }^{14}$ Dewan Redaksi, Ensiklopedi Islam. Jakarta : Ichtiar Baru-Van Hoeve, 1993, hIm. 102. 
Berdasarkan beberapa definisi tentang akhlak di atas, dapat dipahami bahwa akhlak bukanlah perbuatan, melainkan gambaran bagi jiwa yang tersembunyi. Oleh karenanya dapatlah disebutkan bahwa "akhlak itu adalah nafsiyah (bersifat kejiwaan), atau maknawiyah (sesuatu yang abstrak), dan bentuknya yang kelihatan dinamakan mu'amalah (tindakan) atau suluk (perilaku), maka akhlak adalah sumber dan perilaku adalah bentuknya. ${ }^{15}$

Sedangkan akhlak atau pekerti menurut pandangan al-Ghazali bukanlah pengetahuan (ma'rifat) tentang baik dan jahat maupun kodrat (qudrah) untuk baik dan buruk, bukan pula pengamalan $\left(f i^{\prime} l\right)$ yang baik dan jelek, melainkan suatu keadaan jiwa yang mantap (hay'a rasikha fi an-nafs). ${ }^{16}$

Lebih lanjut al-Ghazali menjelaskan bahwa akhlak berarti suatu kemantapan (jiwa) yang menghasilkan perbuatan atau pengamalan dengan mudah, tanpa harus direnungkan dan disengaja. Jika kemantapan itu sedemikian, sehingga menghasilkan amal-amal yang baik -yaitu amal yang terpuji menurut akal dan syari'ah - maka ini disebut akhlak yang baik. Jika amal-amal yang tercelalah yang muncul dari keadaan (kemantapan) itu, maka itu dinamakan akhlak yang buruk. ${ }^{17}$

Sedangkan yang dimaksud dengan akhlak dalam pemakaian kata sehari-hari adalah "akhlak yang baik" (al-akhlâk al-karîmah), umpamanya dikatakan : "orang itu berakhlak", artinya orang itu mempunyai akhlak yang baik, "orang itu tidak berakhlak", artinya orang itu tidak mempunyai akhlak yang baik, atau buruk akhlaknya. Sesungguhnya di samping ada akhlak yang baik ada juga akhlak yang buruk (al-akhlâk al-rodzîllah). ${ }^{18}$

Akhlak atau sistem perilaku ini terjadi melalui suatu konsep seperangkat pengertian tentang apa dan bagaimana sebaiknya akhlak itu harus terwujud. Konsep atau seperangkat pengertian tentang apa dan bagaimana sebaiknya akhlak itu, disusun oleh manusia di dalam sistem idenya. ${ }^{19}$

Dari pengertian-pengertian di atas, dapat dipahami bahwa kata "akhlaq" sebenarnya jamak dari kata "khuluqun", artinya tindakan. Kata "khuluqun"

${ }^{15}$ H.A. Mustofa. Akhlak Tasawuf.,Bandung : Penerbit CV. Pustaka Setia. 1997., hlm. 16.

${ }^{16}$ Al-Ghazali. Ihya 'Ulum ad-Din. Juz III., hlm., 46-47. Cara argumentasi al-Ghazali dalam hal ini agak mirip dengan alasan Aristoteles dalam karnyanya Ethics, 2.5.1105 b-1106a.

${ }^{17}$ Al-Ghazali. Ihya 'Ulum ad-Din. Juz III Ibid., hlm 46. Definisi akhlak ini sesuai dengan definisi Ibnu Miskawyh dalam Tahdzib., hlm., 31. Miskawayh tampaknya mengikuti Galen (Walzer, New Light On Galen's Moral Philosophy", dalam bukunya Greek, hlm., 147. Seperti alGhazalial-Isfahani juga dipengaruhi difinisi akhlak yang diberikan oleh para filosof dalam bukunya Dzari'ah., hlm., 28-30 Dia mencoba membedakan istilah-istilah khuluq, 'ada, thab, dan sajiyyah. Para sufi pendahulu menggugat beberapa diantara mereka dengan berkata, bahwamereka mendifinisikan akhlak menurut hasil atau akibatnya, ketimbang menurut esensi atau makna sebenarnya. Lihat Al-Ghazali. Ihya 'Ulum ad-Din. Juz III., hlm., 46. Lihat juga M. Abul Quasem. Etika Al-Ghazali. Bandung : Penerbit Pustaka. 1988., hlm., 106.

${ }^{18}$ Rachmat Djatnika. Sistem Ethika Islami. op., cit., hlm. 11.

${ }^{19}$ Zakiah Darajat, dkk. Materi Pokok., op., cit., hlm. 238-239 
sepadan dengari kata "khalqun", artinya kejadian dan kata "khaliqun", artinya pencipta dan kata "makhluqun", artinya yang diciptakan. Dengan demikian, rumusan terminologis dari akhlak merupakan hubungan erat antara Khaliq dengan makhluk serta antara makhluk dengan makhluk. ${ }^{\mathbf{2 0}}$

Abuddin Nata, ${ }^{21}$ dalam bukunya yang berjudul Akhlak Tasawuf dan Karakter Mulia menjelaskan bahwa ada lima ciri yang terdapat dalam perbuatan akhlak, yaitu: Pertama, perbuatan akhlak adalah perbuatan yang telah tertanam kuat dalam jiwa seseorang, sehingga telah menjadi kepribadiannya. Kedua, perbuatan akhlak adalah perbuatan yang dilakukan dengan mudah dan tanpa pemikiran. Ini tidak berarti bahwa pada saat melakukan sesuatu perbuatan, yang bersangkutan dalam keadaan tidak sadar, hilang ingatan, tidur atau gila. Pada saat yang bersangkutan melakukan suatu perbuatan ia tetap sehat akal pikirannya dan sadar.

Ketiga, bahwa perbuatan akhlak adalah perbuatan yang timbul dari dalam diri orang yang mengerjakannya, tanpa ada paksaan atau tekanan dari luar. Perbuatan akhlak adalah perbuatan yang dilakukan atas dasar kemauan, pilihan dan keputusan yang bersangkutan. Keempat bahwa perbuatan akhlak adalah perbuatan yang dilakukan dengan sesungguhnya, bukan main-main atau karena bersandiwara. Kelima, sejalan dengan ciri yang keempat, perbuatan akhlak (khususnya akhlak yang baik) adalah perbuatan yang dilakukan karena ikhlas semata-mata karena Allah, bukan karena ingin dipuji orang atau karena ingin mendapatkan sesuatu pujian.

Dengan demikian, secara terminologis pengertian akhlak adalah tindakan yang berhubungan dengan tiga unsur penting, yaitu sebagai berikut.

a. Kognitif, yaitu pengetahuan dasar manusia melalui potensi intelektualitasnya.

b. Afektif, yaitu pengembangan potensi akal manusia melalui upaya menganalisis berbagai kejadian sebagai bagian dari pengembangan ilmu pengetahuan.

c. Psikomotorik, yaitu pelaksanaan pemahaman rasional ke dalam bentuk perbuatan yang konkret. ${ }^{22}$

Terkait dengan perbuatan manusia, Beni Ahmad Saebani dan Abdul Hamid dalam bukunya yang berjudul Ilmu Akhlak menjelaskan bahwa pada dasarnya, perbuatan manusia dimotivasi oleh tiga hal, yaitu:

a. Rasa takut, yaitu perbuatan dilaksanakan karena adanya rasa takut dalam diri manusia, seperti melaksanakan shalat karena takut berdosa dan takut masuk neraka;

\footnotetext{
${ }^{20}$ Hamzah Ya'qub. Etika Islam. Bandung: Diponegoro., 1993., hlm., 11.

${ }^{21}$ Abuddin Nata. Akhlak Tasawuf danKkarakter Mulia. . op., cit., hlm., 4-6

22 Beni Ahmad Saebani dan Abdul Hamid. Ilmu Akhlak. Bandung: CV. Pustaka Setia. 2010., hlm., 15-16
} 
b. Mengharap keuntungan, suatu tindakan yang didorong oleh akibat pragmatis yang menguntungkan untuk kehidupannya, misalnya orang melaksanakan shalat karena ada janji Allah SWT. bahwa yang mendirikan shalat akan masuk surga dan terhindar dari api neraka;

c. Tanpa pamrih, yaitu motivasi yang berbeda dengan dua hal di atas, sering disebut sebagai bentuk perbuatan yang didasarkan pada niat yang ikhlas dan tulus. Tidak karena atas dasar rasa takut atau karena adanya keuntungan yang dijanjikan. Bahkan, meskipun surga dan neraka tidak diciptakan oleh Allah SWT, ia tetap beramal saleh. Jadi, perbuatannya merupakan cara berterima kasih kepada yang memberikan kebajikan dan kasih sayang kepada dirinya. ${ }^{23}$

\section{Pembagian Akhlak}

Akhlak Islami merupakan akhlak yang mutlak untuk dimiliki dan diamalkan oleh setiap individu mengingat eksistensinya yang urgen bagi manusia dalam menjalani kehidupannya baik ketika berinteraksi dengan Tuhan, antarsesama manusia an saat berinteraksi dengan alam.

Terkait dengan masalah akhlak, Beni Akhmad Saebani dan Abdul Hamid, ${ }^{24}$ dalam bukunya yang berjudul Imu Akhlak menjelaskan bahwa secara umum akhlak dalam perspektif ilmu dibagi menjadi dua macam, yaitu sebagai berikut.

a. Akhlak falsafi atau akhlak teoretik

Akhlak falsafi atau akhlak teoretik yaitu akhlak yang menggali kandungan Al-Quran dan As-Sunnah secara mendalam, rasional, dan kontemplatif untuk dirumuskan sebagai teori dalam bertindak. Akhlak falsafi juga mengompromikan ajaran-ajaran yang terkandung dalam AlQuran dan As-Sunnah dengan pemikiran-pemikiran filosofis dan pemikiran sufistik.

Amin Syukur dalam bukunya yang berjudul Rasionalisme dalam Tasawuf mengatakan bahwa akhlak falsafi cenderung mengedepankan pemahaman filosofis tentang berbagai teori yang mengandung rumusan tentang konsep-konsep pergaulan manusia dengan sesama manusia dan komunikasi manusia dengan Allah SWT. Lebih lanjut ia menjelaskan bahwa akhlak falsafi terkadang akhlak falsafi tidak mencerminkan sebagai ilmu akhlak, melainkan lebih pada filsafat. ${ }^{25}$

b. Akhlak amali

Akhlak amali artinya akhlak praktis, yaitu akhlak dalam arti yang sebenarnya, berupa perbuatan, yaitu less talk do more, sedikit bicara banyak bekerja. Akhlak yang menampakkan diri ke dalam perwujudan amal perbuatan yang real, bukan sekadar teori. Jadi, akhlak amali tidak banyak

\footnotetext{
${ }^{23}$ Ibid., hlm., 25

24 Ibid., hlm., 175

25 Amin Syukur. Rasionalisme dalam Tasawuf. Semarang: IAIN Wali Songo., 1994.,
} hlm., 22 
mengumbar janji, melainkan memberi banyak bukti. Misalnya, akhlak dalam beribadah dibuktikan dengan melaksanakan tangga ormas bersangkutan, seperti hak dipilih menjadi ketua umum ormas Islam dibatasi hanya sampai dua penode. Keputusan tersebut secara otomatis menjadi pedoman berakhlak bagi seluruh anggota ormas tersebut. Jika tiba-tiba keputusan itu dilanggar, dapat disebut sebagai akhlak yang tidak terpuji secara jamaah.

Akhlak teoretik atau akhlak falsafi, banyak dikemukakan oleh para tokoh ilmu akhlak yang kemudian dianggap sebagai filsuf muslim, terutama akhlak yang berkaitan dengan komunikasi manusia dengan Sang Pencipta yang dapat diraih melalui berbagai tingkatan akal dan tingkatan kedudukan atau martabat serta kesalehan manusianya masing-masing. ${ }^{26}$

\section{B. Orientasi Akhlak Islami}

\section{Pengertian Akhlak Islami}

Berbicara tentang akhlak, ada akhlak yang termasuk akhlak Islami da nada pula akhlak yang tidak Islami. Pengertian akhlak Islami secara sederhana dapat diartikan sebagai akhlak yang berdasarkan ajaran Islam atau akhlak yang bersifat Islami. Kata Islam yang berada di belakang kata akhlak dalam hal menempati posisi sebagai sifat.

Dengan demikian akhlak Islami adalah perbuatan yang dilakukan dengan mudah, disengaja, mendarah daging dan sebenarnya yang didasarkan pada ajaran Islam. Dilihat dari segi sifatnya yang universal, maka akhlak Islami juga bersifat universal. Namun, dalam rangka menjabarkan akhlak Islam yang universal ini diperlukan bantuan pemikiran akal manusia dan kesempatan sosial yang terkandung dalam ajaran etika dan moral.

Dengan kata lain yang dimaksud dengan akhlak Islami adalah akhlak yang di samping mengakui adanya nilai-nilai universal sebagai dasar bentuk akhlak, juga mengakui nilai-nilai yang bersifat lokal dan temporal sebagai penjabaran atas nilai-nilai yang universal itu. Menghormati kedua orang tua misalnya adalah akhlak yang bersifat mutlak dan universal. Sedangkan bagai-mana bentuk dan cara menghormati kedua orang tua itu dapat dimanifestasikan oleh hasil pemikiran manusia yang dipengaruhi oleh kondisi dan situasi di mana orang yang menjabarkan nilai universal itu berada. Bagi orang Jawa misalnya menghormati kedua orang tua dengan cara sungkem sambil menggelesor di lantai. Bagi orang Sunda, menghormati orang tua dengan cara mencium tangannya. Dan bagi orang Sumatera, menghormati kedua orang tua dengan cara memeliharanya hidup bersama dengan anaknya. Selanjutnya bagi orang Barat

${ }^{26}$ Uraian yang serupa dapat dibaca pada tulisan Muhaimin, dkk. Dimensi-Dimensi Studi Islam. Surabaya: Karya Aditama. 1994.,. Lihat juga Muhaimin, dkk. Kawasan dan Wawasan Studi Islam. Ed. Marno. Jakarta: Prenada Media. 2005. 
berbuat baik kepada kedua orang tua mungkin dilakukan dengan memberikan berbagai fasilitas hidup dan sebagainya.

Hal penting yang perlu ditegaskan di sini adalah bahwa akhlak dalam ajaran agama tidak dapat disamakan dengan etika atau moral, walaupun etika dan moral itu diperlukan dalam rangka menjabarkan akhlak yang berdasarkan agama (akhlak lslami). Hal yang demikian disebabkan karena etika terbatas pada sopan santun antara sesama manusia saja, serta hanya berkaitan dengan tingkah laku lahiriah. Jadi ketika etika digunakan untuk menjabarkan akhlak Islami, itu tidak berarti akhlakIslami dapat dijabarkan sepenuhnya oleh etika atau moral.

Quraish Shihab menjelaska Akhak (Islami) lebih luas maknanya daripada yang telah dikemukakan terdahulu serta mencakup pula beberapa hal yang tidak merupakan sifat lahiriah. Misalnya yang berkaitan dengan sikap batin maupun pikiran. ${ }^{27}$

Selanjutnya akhlak Islami dapat diartikan sebagai akhlak yang menggunakan tolok ukur ketentuan Allah. ${ }^{28}$ Quraish Shihab dalam hubungan ini mengatakan, bahwa tolok ukur kelakuan baik mestilah merujuk kepada ketentuan Allah. Rumusan akhlak Islami yang demikian itu menurut Quraish Shihab adalah rumusan yang diberikan oleh kebanyakan ulama. Perlu ditambahkan, bahwa apa yang dinilai baik oleh Allah, pasti baik dalam esensinya. Demikian pula sebaliknya, tidak mungkin Dia menilai kebohongan sebagai kelakuan baik, karena kebohongan esensinya buruk.

\section{Ruang Lingkup Akhlak Islami}

M. Quraish Shihab, dalam bukunya yang berjudul Wawasan AlQur'an, Ruang lingkup akhlak Islami adalah sama dengan ruang lingkup ajaran Islam itu sendiri, khususnya yang berkaitan dengan pola hubungan. Lebih lanjut ia menjelaskan akhlak diniah (agama/Islami) mencakup berbagai aspek, dimulai dari akhlak terhadap Allah, hingga kepada sesama makhluk (manusia, binatang, tumbuh-tumbuhan, dan benda-benda yang tak bernyawa). ${ }^{29}$ Berbagai bentuk dan ruang lingkup akhlak Islami yang demikian itu dapat dipaparkan sebagai berikut.

\section{a. Akhlak Terhadap Allah}

Akhlak kepada Allah dapat diartikan sebagai sikap atau perbuatan vang seharusnya dilakukan oleh manusia sebagai makhluk, kepada Tuhan sebagai khalik. Sikap atau perbuatan tersebut memiliki ciri-ciri perbuatan akhlaki seperti beriman kepada Allah sebagai Tuhannya, taat dan patuh kepada Allah, serta ridha terhadap takdir Allah atas dirinya. Sehingga dalam menjalani hidup dan kehidupannya selalu sabar dan selalu bersyukur kepada Allah swt sebagaimana telah disebut di atas.

\footnotetext{
${ }^{27}$ M. Quraish Shihab, Wawasan Al-Qur'an, (Bandung: Mizan, 1996) cet.III, hlm. 261.

28 Ibid., hlm. 205.

${ }^{29}$ Ibid., hlm., 261.
} 


\section{b. Akhlak Terhadap Sesama Manusia}

Selain berakhlak kepada Allah swy sebagai pencipta manusia, alam dan segala isinya, manusiapun harus berakhlak terhadap sesama manusia sebagai sesame hamba Allah swt. Terkait dengan akhlak terhadap sesama. Ternyata terdapat banyak sekali rincian yang dikemukakan oleh Allah dalam Al-Qur'an berkaitan dengan perlakuan terhadap sesama manusia. Petunjuk mengenai hal ini bukan hanya dalam bentuk larangan melakukan hal-hal negatif seperti membunuh, menyakiti badan, atau mengambil harta tanpa alasan yang benar, melainkan juga sampai kepada menyakiti hati dengan jalan menceritakan aib seseorang di belakangnya, tidak peduli aib itu benar atau salah, walaupun sambil memberikan materi kepada yang disakiti hatinya itu. Kenyataan yang demikian sungguh menjadi cermin betapa pentingnya akhlak terhadap sesama manusia.

\section{c. Akhlak Terhadap Lingkungan}

Yang dimaksud dengan lingkungan di sini adalah segala sesuatu yang di sekitar manusia, baik binatang, tumbuh-tumbuhan, maupun benda-benda tak bernyawa. Terhadap semua ini, manusia harus berlaku baik yakni berlaku dengan perlakuan akhlak Islami. Yakni tidak boleh berlaku semenamena terhadap mereka, seperti; tidak boleh membunuh binatang tanpa adanya kepentingan, dan tidak boleh melakukan penebangan pohon tanpa ada kepentingan atau manfaat bagi manusia, serta tidak boleh merusak atau menghancurkan alam tanpa adanya faedah bagi manusia.

\section{Kesehatan Mental}

\section{Pengertian Kesehatan Mental}

Kesehatan mental sebagai salah satu cabang ilmu jiwa sudah dikenai sejak abad ke-19, seperti di Jerman tahun 1875 M. ${ }^{30}$ Pada pertengahan abad ke-20 ini ilmu kesehatan mental sudah jauh berkembang dan maju dengan pesatnya sejalan dengan kemajuan ilmu dan teknologi modern. Ia merupakan suatu ilmu yang praktis dan banyak dipraktekkan dalam kehidupan manusia sehari-hari, baik dalam bentuk bimbingan dan penyuluhan yang dilaksanakan di rumahrumah tangga, sekolah-sekolah, kantor-kantor, lembaga-lembaga dan dalam masyarakat. Hal ini dapat dilihat misalnya, dengan berkembangnya klinik-kiinik kejiwaan dan munculnva lembaga-lembaga pendidikan kesehatan mental. Semuanya ini dapat menjadi pertanda bagi perkembangan dan kemajuan ilmu kesehatan mental. ${ }^{31}$

Pada zaman dulu, umumnya dulu pengertian orang pada ilmu kesehatan mental bersifat terbatas dan sempit. Seperti ada yang membatasi pengertian kesehatan mental itu pada absennya seseorang dari gangguan dan penyakit jiwa.

\footnotetext{
${ }^{30}$ Ramayulis Psikologi Agama. Jakarta : Kalam Mulia., 2002., hlm., 112

31 Ibid., hlm., 125
} 
Dengan pengertian ini kesehatan mental itu hanya diperuntukan bagi orang yang terganggu dan berpenyakit jiwa saja, dan tidak diperlukan bagi setiap orang pada umumnya. Di samping itu ada pula yang membatasi pengertian kesehatan mental itu pada "cinta dan kerja", walaupun kata cinta dan kerja dapat ditafsirkan macam-macam maksudnya sesuai dengan ilmu kesehatan mental. Pengertian kesehatan mental semacam ini dikemukakan oleh Sigmund Freud. Williwam Glasser membatasi pengertian kesehatan mental itu pada "rasa tanggung jawab" seseorang dalam memenuhi kebutuhan hidupnya.

Musthafa Fahmi, sebagaimana yang dikutip oleh Muhammad Mahmud, menemukan dua pola dalam mendefiniskan kesehatan mental : Pertama, pola negatif (salabiy), bahwa kesehatan mental adalah terhindarnya seseorang dari segala neurosis (al-amradh al-'ashabiyah) dan psikosis (al-amradhaldzibaniyah). Kedua, pola positif (ijabiy), bahwa kesehatan mental adalah kemampuan individu dalam penyesuaian terhadap diri sendiri dan terhadap lingkungan sosialnya. Pola yang kedua ini lebih umum dan lebih luas dibanding dengan pola pertama.

Terkait dengan kesehatan mental, Zakiyah Dardjat dalam bukunya yang berjudul Kesehatan Mental memberikan definisi sebagai berikut; Pertama Kesehatan mental adalah terhindarnya orang dari gejala-gejala gangguan jiwa (neurose) dan dari gejala-gejala penyakit jiwa (psychose).Kedua. Kesehatan mental adalah kemampuan untuk menyesuaikan diri dengan diri sendiri, dengan orang lain dan masyarakat serta lingkungan di mana ia hidup. ${ }^{32}$

Definisi yang pertama ini, menurut Zakiyah Daradjat banyak mendapat sambutan dari kalangan Psikiatri (kedokteran jiwa). Menurut definisi ini, orang yang sehat mentalnya adalah orang yang terhindar dari segala gangguan dan penyakit jiwa. Secara ringkas menurut Zakiyah Daradjat bahwa orang menderita gangguan jiwa bila: sering cemas tanpa diketahui sebabnya, malas, tidak ada kegairahan untuk bekerja, rasa badan lesu dan sebagainya. Gejalagejala tersebut dalam tingkat lanjutannya terdapat pada penyakit anxiety, neurasthenia, hysteria dan sebagainya. Sedangkan sakit jiwa adalah orang yang pandangannya jauh berbeda dari pandangan orang pada umumnya, jauh dari realitas, yang dalam istilah sehari-hari kita kenal miring, gila dan sebagainya.

Sedangkan definisi kedua menurut pendapat Zakiyah Daradjati lebih luas dan bersifat umum, karena dihubungkan dengan kehidupan secara keseluruhan. Kesanggupan untuk menyesuaikan diri itu, akan membawa orang kepada kenikmatan hidup dan terhindar dari kecemasan, kegelisahan, dan ketidakpuasan. Disamping itu, ia penuh dengan semangat dan kebahagiaan dalam hidup.

Untuk dapat menyesuaikan diri dengan diri sendiri, kita harus lebih dulu mengenal diri kita dan menerimanya sebagaimana adanya, lalu bertindak sesuai

32 Zakiah Darajat. Kesehatan Mental., op., cit., hlm., 11 
dengan kemampuan dan kekurangan yang ada pada kita. ${ }^{33}$ Disamping itu, kita juga harus mengenal, memahami dan meneliti orang lain dari segala segi secara objektif. Jangan kita melihat dan menilai orang lain secara subjektif, yaitu menurut perasaan dan ukuran kita; tapi usahakanlah melihat orang dengan ukuran-ukuran orang itu sendiri. Kita harus mengenal keistimewaan orang disamping kekurangan atau kelemahan-kelemahannya.

Selanjutnya perlu pula diketahui lingkungan, termasuk kaidah-kaidah sosial, peraturan-peraturan, undang-undang, adat kebiasaan, ajaran agama yang dianut dan suasana pada umumnya. Dalam tindakan, pandangan dan apa saja yang terjadi, kita tidak boleh melupakan di mana kita berada, agar tindakan kita tidak bertentangan dengan peraturan dan kebiasaan yang berlaku, serta menyadari sepenuhnya akan kewajiban kita terhadap lingkungan itu.

Adapun menurut definisi yang kedua, orang yang sehat mentalnya ialah orang yang dapat menguasai segala faktor dalam hidupnya, sehingga ia dapat menghindarkan tekanan-tekanan perasaan atau hal-hal yang membawa kepada frustrasi. ${ }^{34}$ Terkait dengan hal tersebut di atas, Marie Jahoda memberikan batasan yang agak luas sedikit tentang pengertian kesehatan mental, sehingga pengertian orang terhadap ilmu kesehatan mental itu juga mengalami perkembangan dan kemajuan. Pengertian yang agak luas dikemukakan oleh Yahoda.

Menurut Marie Jahoda pengertian kesehatan mental tidak hanya terbatas kepada absennya seseorang dari gangguan dan penyakit jiwa, tetapi orang yang sehat mentalnya, juga memiliki sifat atau karakteristik utama sebagai berikut:

a. Memiliki sikap kepribadian terhadap diri sendiri dalam arti ia mengenal dirinya dengan sebaik-baiknya;

b. Memiliki pertumbuhan, perkembangan dan perwujudan diri;

c. Memiliki integrasi diri yang meliputi keseimbangan jiwa kesatuan pandangan dan tahan terhadap tekanan-tekanan kejiwaan yang tcrjadi;

d. Memiliki otonomi diri yang mencakup unsur-unsur pengatur kelakuan dari dalam ataupun kelakuan-kelakuan bebas;

e. Memiliki persepsi mengenai realitas, bebas dari penyimpangan kebutuhan, dan penciptaan empati serta kepekaan sosial;

f. Memiliki kemampuan untuk menguasai lingkungan dan berintegrasi dengannya. ${ }^{35}$

Batasan pengertian kesehatan mental yang dikemukakan Marie Jahoda memang terasa luas, tetapi sungguhpun demikian pengertian yang dikemukakannya belum mencakup seluruh aspek kehidupan manusia, karena

\footnotetext{
33 Ibid., hlm., 11

34 Ibid., hlm., 12

${ }^{35}$ Ramayulis Psikologi Agama., op., cit., hlm., 128
} 
agama belum termasuk di dalamnya. Kesehatan mental adalah pengetahuan dan perbuatan yang bertujuan untuk mengembangkan dan memanfaatkan segala potensi, bakat dan pembawaan yang ada semaksimal mungkin, sehingga membawa kepada kebahagiaan diri dan orang lain; serta terhindar dari gangguan-gangguan dan penyakit jiwa.

Definisi kesehatan mental seperti di atas, sesungguhnya mendorong orang memperkembangkan dan memanfaatkan segala potensi yang ada. Jangan sampai ada bakat yang tidak bertumbuh dengan baik, atau yang digunakan dengan cara yang tidak membawa kepada kebahagiaan, yang mengganggu hak dan kepentingan orang lain."Bakat yang tidak dapat tumbuh dan berkembang dengan baik, akan membawa kepada kegeiisahan dan pertentangan batin.' Dalam pergaulan dengan orang atau keluarganya akan terlihat kaku dan mungkin sekali tidak akan mengindahkan orang, karena ia merasa menderita, sedih, marah kepada dirinya dan orang lain. ${ }^{36}$

Lebih lanjut Zakiah Daradjat merumuskan pengertian kesehatan mental dalam pengertian yang luas dengan memasukkan aspek agama di dalamnya seperti berikut: Kesehatan mental ialah terwujudnya keserasian yang sungguhsungguh antara fungsi-fungsi kejiwaan dan terciptanya penyesuai diri antara manusia dengan dirinya sendiri dan lingkungannya, berIandaskan keimanan dan ketaqwaan, serta bertujuan untuk mencapai hidup yang bermakna dan bahagia di dunia dan di akhirat.

Pengertian "terwujudnya keserasian yang sungguh-sungguh antara fungsifungsi kejiwaan" adalah berkembangnya seluruh potensi kejiwaan secara seimbang sehingga manusia dapat mencapai kesehatan lahir dan batin, jasmani dan rohani dan terhindar dari pertentangan batin, kegoncangan jiwa, kebimbangan dan keragu-raguan serta tekanan perasaan dalam menghadapi berbagai dorongan dan keinginan.

Sedangkan pengertian tentang "terciptanya penyesuaian diri antara manusia dengan dirinya" adalah usaha seseorang untuk melakukan penyesuaian diri yang sehat terhadap dirinya, yakni yang mencakup pembangunan dan pengembangan seluruh potensi dan daya yang terdapat dalam dirinya serta berkemampuan untuk memanfaatkan potensi dan daya itu seoptimal mungkin sehingga penyesuaian diri membawa kepada kesejahteraan dan kebahagiaan diri dari orang lain.

Sedangkan pengertian "penyesuaian diri yang sehat dengan lingkungan atau terhadap masyarakat" adalah mengandung tuntutan kepada seseorang untuk meningkat-kan keadaan masyarakat dan keadaan dirinya sendiri dalam masyarakat dalam arti ia tidak hanya memenuhi tuntutan masyarakat dan mengadakan perbaikan di dalamnya, tetapi juga dapat mengembangkan dirinya secara serasi di dalam masyarakat tersebut. Hal-hal tersebut di atas hanya dapat

${ }^{36}$ Zakiah Darajat. Kesehatan Mental., op., cit., hlm., 12 
dicapai apabila masing-masing individu dan masyarakat sama-sama berusaha meningkatkan diri secara terus menerus dalam batas yang diridhai Allah.

Adapun pengertian mengenai "berlandaskan keimanan dan ketaqwaan" adalah bahwa masalah keserasian yang sungguh-sungguh antara fungsi-fungsi kejiwaan dan penyesuaian diri antara manusia dengan dirinya dan lingkungannya atau masyarakat hanya dapat terwujud dan tercapai secara sempurna apabila usaha itu berdasarkan keimanan dan ketaqwaan kepada Allah SWT. Jadi faktor agama memainkan peranan yang penting dalam mencapai kesejahteraan dan kebahagiaan mental dalam definisi ini.

Dengan masuknya faktor keimanan, ketaqwaan dan ketuhanan dalam pengertian ilmu kesehatan mental, maka pengertian kesehatan mental terasa luas dan dalam karena sudah mencakup seluruh aspek dari kehidupan manusia. Dan sekaligus menunjukkan bahwa agama mempunyai hubungan yang erat dengan kesehatan mental. ${ }^{37}$

\section{Aliran-Aliran Kesehatan Mental.}

Pandangan Islam terhadap kesehatan mental merupakan koreksi dan penyempurnaan terhadap teori-teori kesehatan mental yang telah banyak dirumuskan oleh psikolog kontemporer. Dalam psikologi kontemporer ditemuo berbagai jenis aliran. Di antara aliran-aliran tersebut yang terkenal adalah:

\section{a. Aliran Psikoanalitik}

Aliran ini dikenal dengan tokoh yang mempeloporinya yaitu Sigmund Freud dengan pandangan bahwa manusia adalah produk evolusi vang terjadi secara kebetulan dan merupakan makhluk biologis. Psiko-analisis merupakan satu sistem dinamis dari psikologi yang mencari akar tingkah laku manusia di dalam dorongan il.m konflik yang tidak disadari. Freud selanjutnya memandang bahwa tingkah laku manusia itu terjadi karena terdapatnya interaksi antara tiga alat dalam personaliti, yang disebut dengan Id. Ego dan super ego. ${ }^{38}$

Psikoanalitik memandang bahwa kesehatan mental itu akan diperoleh apabila ego mencapai kemenangan dalam pertarungan yang terjadi antara

${ }^{37}$ Ramayulis Psikologi Agama., op., cit., hlm., 129

38 Id bekerja menurut prinsip kelezatan, dan tidak dapat mengamlul pertimbanganpertimbangan sosial dan tidak dapat pula bersiial realistik, tetapi ia sanggup membentuk khayalan-khayalan untui pemuasannya, meskipun pemuasan yang ia peroleh itu buk.in pemuasan dalam arti yang sesungguhnya. Ego muncul unuik memuaskan Id, Ego bekerja di atas prinsip realitas dan menggunakan potensi intelektual. Oleh karena itu kadang-kadang ia mengekanj kemauan $I d$, dan kadang-kadang pula ia menangguhkannya. Sedano kan super ego bekerja di atas prinsip nilat- nilai akhlak dan ben kenaan dengan yang betul dan yang salah. Oleh karena itu super ego sering juga dikatakan dengan hati nurani. Lihat Ramayulis Psikologi Agama., Ibid., hlm., 141 
ketiganya. Namun tampaknya hasil (kesehatan mental) yang ia peroleh itu, bukanlah hasil yang sebenarnya, melainkan hasil yang semu. Sebab dibalik keberhasilan itu pertarungan-pertarungan di antara ketiganya akan terus berlangsung. Ego hampir selalu saja berseberangan dengan $I d$. Kemudian datang super ego yang mencoba melerai keduanya, yang pada dasarnya semakin memperluas arena pertarungan. Dengan demikian, maka manusia adalah makhluk yang penuh dengan sikap pesimis dan tidak akan pernah memperoleh kesehatan mental yang sebenar-benarnya. ${ }^{39}$

Agaknya para penganut aliran pesimis akan dapat dicapai kesehatan mental yang sempurna karena dalam dirinya selalu terjadi pertentangan sebagai frame atau kodrat hidup manusia. Penganut aliran psikoanalitik lainnya yakni Erich Fromm. Ia pesimis bahwa manusia akan dapat mencapai kesehatan mental dalam arti yang sebenarnya. Menurutnya manusia hanya sanggup mendapatkan sebagian kesehatan mental saja. Sebab ia dengan kondisi yang saling bertarung tidak akan mungkin mencapai kebahagiaan dan kemajuan sekaligus. Di dalam pertarungan itu, maka manusia berada di dua persimpangan. Apabila ia memuaskan naluri dengan sepuas-puasnya berarti disitulah letak kebiadaban. Sedangkan apabila ia "mengecewakan" sebagian naluri, berarti disitulah letaknya pertumbuhan budaya manusia. Ini berarti bahwa kemajuan manusia itu menghendaki tekanan-tekanan mental. ${ }^{40}$

\section{b. Aliran Behavioristik}

Aliran ini dipelopori oleh Thorndike dan John B. Watson. Aliran ini menitikberatkan kepada tingkah laku manusia. Mereka memandang manusia ibaratkan mesin. Tingkah lakunya merupakan respon dari setiap stimulusi yang dapat dan dapat ditafsirkan berdasarkan perubahan-perubahan fisiologi dan neurologi yang berlaku. Tingkah laku itu didapatkan karena kebiasaankebiasan yang dipelajarinya. Oleh karena itu aliran ini sangat mementingkan lingkungan. Asumsi dasarnya bahwa tingkah laku manusia sebagai manifestasi ke-jiwaannya merupakan respon dari stimulus yang diterimanya dari lingkungan. Ketika manusia dilahirkan ia tidak membawa bakat apapun, mereka ber-kembang berdasarkan stimulus yang diterima dari lingkungannya. 41

Aliran ini berpendapat bahwa kesehatan mental adalah kesanggupan seseorang untuk memperoleh kebiasaan yang sesuai dan dinamik yang dapat menolongnya berintegasi dengan lingkungan, dan menghadapi suasana-

${ }^{39}$ Ramayulis Psikologi Agama Ibid., hlm., 142

${ }^{40}$ Aliran psikoanalitik ini mendapat kritik dari berbagai pakar psikologi karena aliran ini dipandang sangat menyederhanakan energi dasar dalam diri manusia hanya pada instink libido.

${ }^{41}$ lbid., hlm., 143 
suasana yang memerlukan pengambilan keputusan. Dengan kata lain, orang yang sehat mentalnya adalah orang yang mampu ber-adjusment secara baik dan dinamis dengan lingkungan di mana ia berada. ${ }^{42}$

\section{c. Aliran Humanistik}

Aliran ini dipelopori oleh Abraham Maslow, seorang yang semula beraliran behavioristik, merasa tidak puas dengan aliran tersebut. Ia meragukan keadaan manusia yang dapat dikondisikan seperti mesin yang mengatur stimulus - respon (S-R). Aliran ini berpendapat bahwa pengkajian terhadap manusia harus didekati dari sudut kemanusiaannya. Manusia dilengkapi dengan berbagai potensi yang bebas dipergunakan menurut kemanuannya. Oleh karena itu kesehatan mental, menurut aliran ini, adalah kesadaran manusia terhadap potensi-potensinya dan kebebasannya untuk mencapai apa yang ia kehendaki dengan cara yang dipilihnya. Dengan kata lain, bahwa orang yang sehat mentalnya menurut aliran ini adalah orang sadar akan potensi yang dimilikinya, kemudian secara bebas ia dapat mengembangkan sesuai dengan apa yang menjadi kehendaknya. ${ }^{43}$

Dari ketiga aliran psikologi di atas tampak bahwa ketiga-tiganya mendasarkan teori kesehatan mentalnya hanya pada konsep dasar manusia yang sebenamya belum utuh. Kekurangutuhan itu akan tampak bila diteliti dengan seksama, ternyata ketiga aliran tersebui membicarakan konsep kepribadian manusia. namun belum me-nyinggung bagaimana kaitannya dengan Sang Pencipta. Oleh karena itu, orang kesulitan untuk menjawab bagaimana sebenamya tentang konsep jiwa/mental yang sehat, tampaknva sulit ditentukan jawaban yang tuntas. Masing-masing aliran belum mampu mengembangkan seluruh potensi manusia, sehingga aliran humanistik yang dikatakan sebagai perumus kajian tersempurna mengenai manusiapun ternyata masih belum sempuma menurut Islam.

Aliran Humanistik pada dasarnya mirip dengan konsep Islam, karena memandang manusia dari sudut kemanusiaannya, namun demikian ada perbedaannya yakni aliran ini terlalu anthropo centris, yang memberi peluang

${ }^{42}$ Aliran ini mendapat kritikan karena menganggap manusia iiu sebagai makhluk hedonis yang mempunyai motif tunggal untuk menyesuaikan diri (adjusment) dengan lingkungan fisik dan sosial, Di samping itu aliran ini mengabaikan aspek spiritual manusia dan mementingkan aspek biologis saja.

${ }^{43}$ Aliran humanistik juga mempunyai kelemahan karena ia memandang bahwa manusia memiliki potensi-potensi positif saja. dengan kata lain, manusia ialah makhluk super potensi. Secara singkat, pandangan psikologi humanistik seperti itu membuat teori kesehatan mentalnya berbeda dengan aliran sebelumnya. Menurut aliran ini, orang sehat mental adalah orang yang mampu meng-aktualisasikan segala potensi insaniyahnya. Sehingga potensi positifnya lebih tampak dan potensi buruknya tertutupi. Sebaliknya, orang yang tidak sehat mental ialah orang yang tidak mampu lagi mengaktualisasikan seluruh potensi humanistiknya. Ibid., hlm., 144 
manusia menganggap dirinya sebagai penguasa yang mampu memainkan peranan Tuhan.

Menurut pandangan Islam orang sehat mentalnya ialah orang yang berprilaku, fikiran, dan perasaannya mencerminkan dan sesuai dengan ajaran Islam. Ini berarti, orang yang sehat mentalnya ialah orang yang di dalam dirinya terdapat keterpaduan antara perilaku, perasaan, pikirannya dan jiwa keberagamaannya. Dengan demikian, tampaknya sulit diciptakan kondisi kesehatan mental dengan tanpa agama. Bahkan dalam hal ini Malik B, Badri berdasarkan pengamatannya berpendapat, keyakinan seseorang terhadap Islam sangat berperan dalam membebaskan jiwa dari gangguan dan penyakit kejiwaan. Disinilah peran penting Islam dalam membina kesehatan mental. ${ }^{44}$

\section{Wawasan dan Orientasi Kesehatan Mental}

\section{a. Wawasan dan Orientasi Kesehatan Mental}

Berdasarkan orientasi di atas Hanna Djumhana Bastaman menyimpulkan pandangan tersebut menjadi empat wawasan kesehatan mental dengan masing-masing orientasinya, yaitu:

1) Wawasan yang berorientasi sinitomatis, menganggap bahwa hadirnya gejala (symptoms) dan ketuhan (compliants) adalah tanda adanya gangguan atau penyakit yang diderita seseorang Sebaliknya tidak adanya gejala dan keluhan tersebut adalah pertanda seseorang itu sehat.

2) Wawasan yang berorientasi penyesuaian diri, berpandangan bahwa kemampuan seseorang untuk menyesuaikan diri dalam arti luas merupakan unsur utama kesehatan mental.

3) Wawasan yang beronientasi pengembangan potensi pribadi, berpandangan bahwa manusia adalah makhluk yang memiliki potensi dan kualitas. Seseorang dinyatakan sehat apablia ia mampu untuk dapat mengembangkan potensi-potensi yang baik itu secara optimal, sehingga bermanfaat bagi diri sendiri dan orang lain, dengan memperhatikan norma-norma dan nilai-nilai etis yang dianutnya.

4) Wawasan yang berorientasi agama, berpandangan bahwa agama atau kerohanian dapat menunjang kesehatan mental seseorang Bahkan kesehatan mental itu diperoleh sebagai akibat dari keimanan dan ketakwaan kepada Tuhan, serta menerapkan tuntunan-tuntunan keagamaan dalam hidupnya. ${ }^{45}$

\section{b. Orientasi Kesehatan Mental}

Saparinah Sadli sebagaimana dikutip oleh Ramayulis dalam bukunya yang berjudul Psikologi Agama mencoba menjabarkan orientasi kesehatan mental berdasarkan aliran-aliran yang disebutkan di atas yaitu:

\footnotetext{
${ }^{44}$ Ibid., hlm., 146.

${ }^{45}$ Ibid., hlm., 148
} 
1) Orientasi klasik, yang dalam hal ini diwaktu oleh aliran Psiko-analitik Menurut aliran ini, seseorang dinyatakan sehat mentalnya apabila ia tidak mempunyai keluhan-keluhan tertentu seperti cemas, rendah diri, tegang dan sebagainya, di mana semua keluhan itu menimbulkan perasaan sakit.

2) Orientasi pada aspek penyesuaian diri (adjusment) yang dalam hal ini diwakili oleh aliran Behavioristik

Menurut aliran ini, seseorang dinyatakan sehat apabila ia mampu menyesuaikan dirinya secara aktif, efektif dan menyenangkan sesuai dengan tuntutan realitas sekitarnya. Ukuran keberhasilannya didasar-kan pada skala ukuran yang berlaku dalam masyarakat dimana ia berada.

3) Orientasi pada aspek pengembangan Potensi, yang dalam hal ini diwakili oleh aliran Humanistik

Menurut aliran ini, seseorang dinyatakan sehat apabila ia mampu mengembangkan potensi-potensinya di tengah masyarakat di mana ia tinggal, sehingga pengembangannya itu diterima dan diakur oleh masyarakat dan oleh dirinya sendiri.

4) Orientasi pada aspek intra psikis/agama

Menurut aliran ini seseorang dianggap sehat apabila ia mampu memiliki apa yang dianggap baik dan menolak apa yang di anggapnya buruk berdasarkan pedoman normatif sesuai dengan ajaran agama yang dianutnya.

Tampaknya keempat orientasi itu merupakan satu kesatuan. Masing-masing orientasi saling berintegrasi guna menciptakan kesehatan mental yang sempurna. 46

\section{Pola dalam Kesehatan Mental.}

Hanna Djumhana Bastaman lebih luas menyebut empat pola yang ada dalam kesehatan mental, yaitu pola simtomatis, pola penyesuaian diri, pola pengembangan potensi, dan pola agama. ${ }^{47}$

Pertama, pola simtomatis adalah pola yang berkaitan dengan gejala (symtoms) dan keluhan (compliants), gangguan atau penyakit naftaniah. Kedua, pola penyesuaian diri adalah pola yang berkaitan dengan keaktifan seseorang dalam memenuhi tuntutan lingkungan tanpa kehilangan harga diri. Atau memenuhi kebutuhan pribadi tanpa mengganggu hak-hak orang lain. Kesehatan mental berarti kemampuan seseorang untuk menyesuaikan diri secara aktif terhadap lingkungan sosialnya.

\footnotetext{
${ }^{46}$ Ramayulis Psikologi Agama Ibid., hlm., 147-148

47 Ibid., hlm., 126.
} 
Ketiga, pola pengembangan diri adalah pola yang berkaitan dengan kualitas khas insani (human qualities) seperti kreativitas, produktivitas, kecerdasan, tanggung jawab dan sebagainya. Kesehatan mental berarti kemampuan individu untuk memfungsikan potensi-potensi manusiawinya secara maksimal, sehingga ia memperoleh manfaat bagi dirinya sendiri maupun bagi orang lain.

Keempat, pola agama adalah pola yang berkaitan dengan ajaran agama. Kesehatan mental adalah kemampuan individu untuk melaksanakan ajaran agama secara benar dan baik dengan landasan keimanan dan ketaqwaan.

\section{SIMPULAN}

Diskursus tentang akhlak seakan tak pernah habis dan selalu saja menyedot perhatian banyak pihak, baik dari kalangan teoretisi maupun dari kalangan praktisi dan akademisi. Akhlak seringkali menjadi barometer dari kejiwaan dan kesehatan mental seseorang. Hal ini tidak bisa dinegasikan mengingat dalam banyak kasus ditemukan orang yang akhlaknya tidak baik ternyata mentalnya tidak sehat. Dengan kata lain; orang yang mentalnya tidak sehat ternyata berimplikasi kepada munculnya akhlak (sikap dan perilaku) yang juga tidak baik. Ini sesungguhnya menunjukkan bahwa akhlak memiliki hubungan yang signifikan dengan kesehatan mental, begitupun sebaliknya, yakni orang yang akhlaknya tidak baik mentalnya pun tidak baik (kesehatan mentalnya terganggu).

\section{DAFTAR PUSTAKA}

Abuddin Nata. Akhlak Tasawuf dan Karakter Mulia. Jakarta; PT. RajaGrapindo Persada. 2014.

Ahmad Amin, Al-akhlâq. terjemahan Farid Ma'ruf dalam "Etika (Ilmu akhlaq). Jakarta : Penerbit Bulan Bintang, 1988.

Al-Ghazali, Ihyâ 'Ulûm al-Dîn. jilid 3. Beirut : Dar al-Fikr, t.t.

Amin Syukur. Rasionalisme dalam Tasawuf. Semarang: IAIN Wali Songo., 1994.

Beni Ahmad Saebani dan Abdul Hamid. Ilmu Akhlak. Bandung: CV. Pustaka Setia. 2010.

Dewan Redaksi, Ensiklopedi Islam. Jakarta : Ichtiar Baru-Van Hoeve, 1993.

H.A. Mustofa. Akhlak Tasawuf.,Bandung : Penerbit CV. Pustaka Setia. 1997.

H.M. Arifm, Filsafat Pendidikan Islam, (Jakarta; Bumi Aksara, 1994), cet.IV.

H.M. Arifm, Ilmu Pendidikan Islam, Jakarta: Bumi Aksara, 1991, cet.l.

Hamzah Ya'qub. Etika Islam. Bandung: Diponegoro., 1993.

Ibn Miskawaih, Tahdzîb al-Akhlâq wa Tathhîr al-A'raq. Mesir : al-Maktabat alMishriyyah, 1934.

Imran Effendy Hasibuan. Pemikiran Akhlak Syekh Abdurrahman Shiddiq alBanjari. Pekanbaru: LPNU Press. 2003

Jamil Shaliba, al-Mu'jam al-Falsafi, Juz I, Mesir: Dar al-Kitab al-Mishri, 1978, Kamus Besar Bahasa Indonesia, Jakarta: Balai Pustaka, 1991.

M. Abul Quasem. Etika Al-Ghazali. Bandung : Penerbit Pustaka. 1988. 
M.Quraish Shihab, Wawasan Al-Qur'an, Bandung: Mizan, 1996 cet.III.

Mansur Ali Rajab, Ta'ammulat fi Falsafah al-Akhlaq, Mesir: Maktabah al-Anjalu al-Mishriyah, 1961.

Muhaimin, dkk. Dimensi-Dimensi Studi Islam. Surabaya: Karya Aditama. 1994.

Muhaimin, dkk. Kawasan dan Wawasan Studi Islam. Ed. Marno. Jakarta: Prenada Media. 2005.

Nasru HS. Akhlak Tasawuf. Yogyakarta: Aswaja Presindo., 2015.

Rachmat Djatnika. Sistem Ethika Islami. Jakarta : Pustaka Panji Mas, 1969.

Ramayulis Psikologi Agama. Jakarta : Kalam Mulia., 2002.

Zakiah Darajat. Kesehatan Mental Jakarta: PT. Gunung Agung. 1978.

--------., Materi Pokok Pendidikan Agama Islam. Jakarta : Proyek Pembinaan

Pendidikan Agama Isslam Pada Perguruan Tinggi Depag dan Universitas Terbuka Depdikbud. 1993. 
Prophetic Vol. I, No. I, November 2018 